\title{
PENGELOLAAN ENERGI NASIONAL: MODAL PEMBANGUNAN BANGSA
}

\author{
National Energy Management: As a Nation Development Capital \\ Thoriq Ramadani \\ Kementerian Energi dan Sumber Daya Mineral \\ email: thoriqramadani@gmail.com
}

Naskah diterima tanggal 14 November 2018, Naskah direvisi 19 November 2018, Naskah disetujui 6 Desember 2018

\begin{abstract}
Abstrak
Karya tulis ini dilatarbelakangi implementasi Peraturan Pemerintah No. 79 tentang Kebijakan Energi Nasional yang menjelaskan bahwa untuk memenuhi penyediaan dan pemanfaatan energi diperlukan pencapaian sasaran KEN, salah satunya adalah terwujudnya paradigma baru bahwa sumber energi merupakan modal pembangunan nasional. Penilitian ini untuk mengetahui (1) bagaimana pengelolaan energi yang ada saat ini dan (2) pengelolaan energi seperti apa yang dibutuhkan untuk keberhasilan visi Indonesia 2045. Metodologi penelitian bersifat kualitatif dengan jenis data yang digunakan adalah data primer dan sekunder.Pengumpulan data primer dilakukan melalui wawancara dan pengumpulan data sekunder dilakukan melalui studi kepustakaan atau tinjauan literatur. Hasil penelitian ini yaitu (1) pengelolaan energi yang ada saat ini belum optimal dalam implementasi paradigma energi sebagai modal pembangungan nasional, dan (2) pengelolaan energi yang dibutuhkan untuk keberhasilan visi Indonesia 2045 adalah kelembagaan yang dapat mengimplementasikan paradigma energi sebagai modal pembangunan nasional dengan cara dapat menerjemahkan kebijakan ke dalam implementasi dengan jelas dan konsisten.
\end{abstract}

Kata Kunci: Implementasi kebijakan, Pengelolaan Energi, Modal Pembangunan

\begin{abstract}
This paper is motivated by the implementation of Government Regulation No. 79 concerning National Energy Policy which explains that to meet the provision and utilization of energy, it is necessary to achieve KEN targets, one of which is the realization of a new paradigm that energy sources are national development capital. This research is to find out (1) how current energy management is and (2) what kind of energy management is needed for the success of Indonesia's vision of 2045. The research methodology is qualitative with the types of data used are primary and secondary data. Primary data collection is done through interviews and secondary data collection is done through literature studies or literature reviews. The results of this study are (1) energy management that is currently not optimal in implementing the energy paradigm as a national development capital, and (2) energy management needed for the success of Indonesia's vision of 2045 is an institution that can implement the energy paradigm as a national development capital by can translate policies into implementation clearly and consistently.
\end{abstract}

Keywords: Policy implementation, Energy management, Development Capital

\section{PENDAHULUAN}

A manat Undang-Undang Dasar 1945 berbunyi, "Bumi air dan kekayaan alam yang terkandung di dalamnya dikuasai oleh Negara dan dipergunakan untuk sebesar-besarnya kemakmuran rakyat."Undang-Undang (UU) Nomor 30 Tahun 2007 tentang Energi menjelaskan bahwa peranan energi sangat penting bagi peningkatan kegiatan ekonomi dan ketahanan nasional, sehingga pengelolaan energi yang meliputi penyediaan, pemanfaatan dan pengusahaannya harus dilaksanakan secara berkeadilan, berkelanjutan, rasional, optimal dan terpadu.

Energi merupakan faktor penting dalam kekuatan bangsa bahkan dipandang menjadi salah satu faktor kedaulatan bangsa.Kebijakan pengelolaan energi didasari prinsip berkeadilan, berkelanjutan, dan berwawasan lingkungan guna terciptanya kemandirian energi dan ketahanan energi nasional.Dalam Peraturan Pemerintah (PP) Nomor 79 Tahun 2014 tentang Kebijakan Energi Nasional (KEN) menjelaskan bahwa untuk memenuhi penyediaan dan pemanfaatan energi diperlukan pencapaian sasaran KEN, salah satunya adalah terwujudnya paradigma baru bahwa sumber energi merupakan modal pembangunan nasional. Kemandirian energi dapat dicapai dengan menjadikan energi sebagai modal pembangunan nasional. Kedaulatan energi sejauh ini belum terdefinisi dalam nomenklatur kebijakan di Indonesia, namun jika ingin mewujudkan kedaulatan energi, merupakan kenis- 
cayaan dengan mewujudkan kemandirian energi dan ketahanan energi nasional.

Pengelolaan energi selama ini menempatkan sumber daya energi sebagai komoditi ekspor untuk menghasilkan devisa. Hal ini mengakibatkan pasokan energi dalam negeri tidak terjamin dengan baik, peningkatan nilai tambah (adding value) tidak berjalan optimal dan hilangnya penciptaan lapangan kerja baru yang menjadi salah satu penghambat pertumbuhan perekonomian.

Maka dari itu, paradigma pengelolaan energi perlu diimplementasikan dengan menjadikan energi sebagai modal pembangunan nasional, harapan yang didapat adalah meningkatkan nilai tambah yang memberikan penerimaan negara dari sektor energi dan multiplier effects atau dampak yang positif dari paradigma tersebut dapat dimanfaatkan oleh masyarakat, seperti penciptaan nilai tambah di dalam negeri dan penyerapan tenaga kerja dan bisa mendorong pengembangan sektor energi antara lain melalui penemuan dan peningkatan cadangan baru energi fosil, pengembangan Energi Baru Terbarukan (EBT), pemulihan fungsi lingkungan hidup pasca penambangan dan memaksimalkan konservasi sumber daya energi.

\section{Rumusan Masalah}

Pengelolaan energi dengan menjadikan energi sebagai modal pembangunan nasional sangat penting untuk mewujudkan kedaulatan bangsa Indonesia, namun permasalahan yang ada saat ini dirumuskan masalah penelitian sebagai berikut:

1. Bagaimana pengelolaan energi yang ada saat ini?

2. Pengelolaan energi seperti apakah yang dibutuhkan untuk keberhasilan visi Indonesia 2045.

\section{Tujuan dan Manfaat Penelitian}

Tujuan dari penilitian adalah mengetahui implementasi kebijakan pengelolaan energi sebagai modal pembangunan nasional.

Dengan mengetahui implementasi kebijakan pengelolaan energi sebagai modal pembangunan nasional dapat memberi kontribusi dalam pengembangan ilmu pengetahuan kebijakan pembangunan. Hasil dari penilitian ini diharapkan dapat menjadi rekomendasi kebijakan bagi pemerintah dalam pengelolaan energi yang berparadigma sebagai modal pembangunan nasional.

\section{TINJAUAN PUSTAKA}

\section{Implementasi Kebijakan Publik}

Menurut Thomas R. Dye dalamUnderstanding Public Policy mengatakan "Public Policy is what- ever the government choose to do or not to do". (Dye, 2011, p. 1) Kebijakan publik adalah apapun pilihan pemerintah untuk melakukan sesuatu atau tidak melakukan sesuatu. Nugroho menyampaikan "Di negara-negara berkembang, di mana kebijakan publik belum menjadi concern dari kekuasaan maka yang terjadi adalah kebijakan publik dalam diskusi akademik tidak senantiasa sesuai dengan kenyataan praktik." (Nugroho, 2015, p. 205).

Budi Winarno mengatakan "Implementasi kebijakan adalah salah satu tahap kebijakan publik, antara kebijakan dan konsekuensi-konsekuensi kebijakan bagi masyarakat yang dipengaruhinya." (Winarno, 2014, p. 177)Kiviniemi dalam Purwanto \& Sulistyastuti menyampaikan (Purwanto \& Sulistyastuti, 2015, p. 63).Implementasi kebijakan publik biasanya merupakan proses yang kompleks. Seringkali membutuhkan waktu bertahun-tahun, dan melibatkan beberapa kelompok pelaku yang berbeda di berbagai kelompok aktor dalam tahapan yang berbeda.

George C. Edwards III dalam Implementing Public Policy menjelaskan faktor-faktor yang mempengaruhi dalam implementasi kebijakan publik adalah komunikasi, sumberdaya, disposisi dan struktur birokrasi.(Edwards III, 1980). Empat faktor yang berpengaruh dalam implementasi kebijakan bekerja secara simultan dan berinteraksi satu sama lainnya baik itu membantu maupun justru menjadi penghambat implementasi kebijakan.

\section{Energi sebagai Modal Pembangunan Bangsa}

"Energy sector is not only closely associated to the economic progress of a state but also determined the standing of a state in the committee of nations." (Khalid \& Mukhtar, 2016, p. 101). Sektor energi tidak hanya terkait erat dengan kemajuan ekonomi suatu negara tetapi juga menentukan kedudukan negara dalam komite bangsa-bangsa Energi mempunyai posisi yang sangat strategis dalam pembangunan suatu negara, khususnya dalam mengakselerasi kemajuan ekonomi Negara. (Santoso, 2017, p. 28) Energi mempunyai peran yang strategis dalam pertumbuhan ekonomi suatu negara. Di Indonesia, selain berfungsi sebagai katalisator pertumbuhan ekonomi, energi juga menjadi sumber penerimaan negara. (Kurniawati, 2017)

Pengelolaan energi di Indonesia berdasarkan KEN memiliki tiga prinsip dasar yakni berkeadilan, berkelanjutan dan berwawasan lingkungan dengan ditujukan untuk modal pembangunan guna sebesarbesarnya kemakmuran rakyat, dengan cara mengoptimalkan pemanfaatannya bagi pembangunan ekonomi nasional, penciptaan nilai tambah di dalam negeri dan penyerapan tenaga kerja. 
Dalam KEN juga dijelaskan sasaran penyediaan dan pemanfaatan enregi primer dan energy final sebagai berikut, yaitu (1) terpenuhinya penyediaan energi primer pada tahun 2025 sekitar 400 MTOE dan pada tahun 2050 sekitar 1.000 MTOE, (2) tercapainya pemanfaatan energy primer per kapita pada tahun 2025 sekitar 1,4 TOE dan pada tahun 2050 sekitar 3,2 TOE, (3) terpenuhinya penyediaan kapasitas pembangkit listrik pada tahun 2025 sekitar $115 \mathrm{GW}$ dan pada tahun 2050 sekitar $430 \mathrm{GW}$ dan (4) tercapainya pemanfaatan listrik per kapita pada tahun 2025 sekitar $2.500 \mathrm{KWh}$ dan pada tahun 2050 sekitar $7.000 \mathrm{KWh}$.

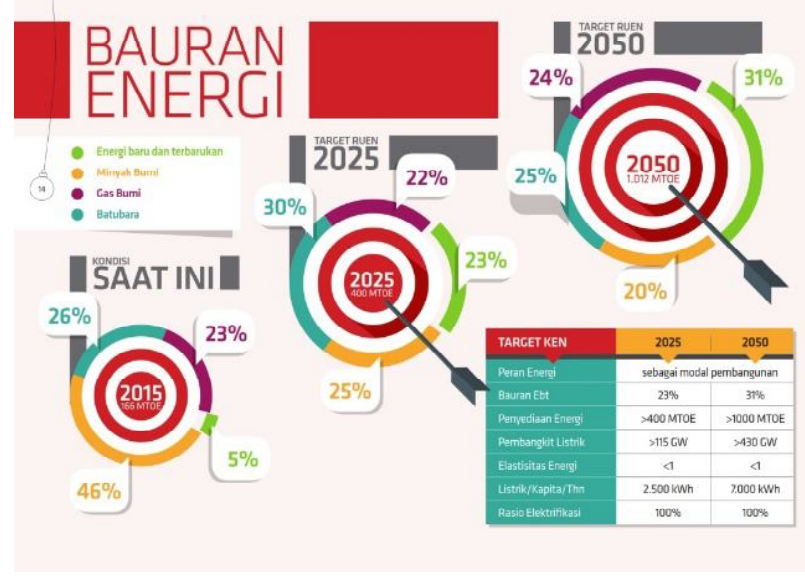

Gambar 1.

Target Bauran Energi. (Sumber: Dewan Energi Nasional, 2017, p. 14)

Selanjutnya, untuk pemenuhan penyediaan energi dan pemanfaatan energi, diperlukan pencapaian sasaran KEN di antaranya tercapainya rasio elektrifikasi sebesar 85 persen pada tahun 2015 dan mendekati sebesar 100 persen pada tahun 2020 dan tercapainya bauran energi primer yang optimal pada tahun 2025 peran Energi Baru dan Energi Terbarukan paling sedikit 23 persen dan pada tahun 2050 paling sedikit 31 persen sepanjang keekonomiannya terpenuhi.

\section{Visi Indonesia 2045}

Dalam Visi Indonesia 2045 yaitu berdaulat, maju, adil dan makmur, yang dijabarkan dalam pilar-pilar pembangunan yang salah satu pilar pembangunan adalah pembangunan ekonomi yang berkelanjutan. Indonesia menjadi negara maju dan salah satu ekonomi terbesar di dunia dengan digerakkan oleh investasi dan perdagangan, industri, pariwisata, maritim, dan jasa, serta didukung oleh infrastruktur yang andal dan ketahanan pangan, energi, dan air yang kuat.Komitmen terhadap lingkungan hidup terus dijaga bagi keberlanjutan pembangunan.(Bappenas, 2018).

Sesungguhnya, Visi Indonesia 2045 khususnya pilar pembangunan ekonomi yang berkelanjutan dengan peningkatan energi sejalan dengan KEN. Energi sebagai modal pembangunan melalui peningkatan peran EBT melalui (1) peran EBT ditingkatkan menjadi 30 persen pada tahun 2045, (2) pembangkit tenaga listrik ditingkatkan menjadi lebih dari $430 \mathrm{GW}$, (3) rasio elektrifikasi 100 persen sejak tahun 2020 dan pasokan energi per kapita menjadi 7 ribu per kWh, (4) pengembangan infrastruktur ketenagalistrikan menerapkan konsep kepulauan dan (5) pemenuhan kebutuhan energi memperhatikan dampak terhadap lingkungan hidup.(Bappenas, 2018).

\section{Kemandirian Energi}

Dalam PP KEN dijelaskan Kemandirian Energi adalah terjaminnya ketersediaan Energi dengan memanfaatkan semaksimal mungkin potensi dari sumber dalam negeri. Kemandirian energi dapat terwujud melalui sumber daya energi tidak dijadikan sebagai komoditas ekspor semata tetapi sebagai modal pembangunan nasional, kemandirian dalalm pengelolaan energi, pengelolaan sumber saya energi secara optimal, terpadu, dan berkelanjutan, pemanfaatan energi secara efisien di semua sektor. Selain itu, pengembangan kemampuan teknologi, industri dan jasa energi dalam negeri agar mandiri dan meningkatkan kapasitas sumber daya manusia, terciptanya lapangan kerja dan terjaganya kelestarian fungsi lingkungan hidup.

\section{Ketahanan Energi}

Dalam PP KEN dijelaskan ketahanan energi adalah suatu kondisi terjaminnya ketersediaan energi dan akses masyarakat terhadap energi pada harga yang terjangkau dalam jangka panjang dengan tetap memperhatikan perlindungan terhadap lingkungan hidup.Secara sederhana, International Energy Agency (IEA) mendefinisikan ketahanan energi sebagai ketersediaan sumber energi yang tidak terganggu pada harga yang terjangkau.(Kurniawati, 2017, p. 31).

Populasi yang terus meningkat, perekonomian yang berkembang dan persaingan pasar bebas menjadikan ketahanan energi sebagai perhatian utama di seluruh dunia. McMillan (2008)"Energy security from a political-military dimension is to fulfill the energy desires of martial forces but in the light of contemporary political-economic international system." (Khawaja \& Ur Rehman, 2016, p. 504) Ketahanan energi dari dimensi militer-politik adalah untuk memenuhi keinginan untuk kekuatan tetapi dalam sistem ekonomi politik-ekonomi kontemporer.

"The logic of energy security is changing, with supply security being de-emphazied, governance and collective sollutions are being increasingly 
emphazied." (Bayraktar, 2018, p. 45) Logika ketahanan energi berubah, dengan tidak berfokus pada keamanan pasokan, pemerintahan dan semakin menekankan pada pengumpulan kolektif.

\section{Kedaulatan Energi}

Secara singkat, kedaulatan energi sebuah negara bersumber dari terwujudnya kemandirian dan ketahanan energi negara tersebut. Sebuah negara dapat membuat kebijakan pengelolaan energinya tanpa masuk campur tangan negara lain. Kedaulatan energi sebuah negara merupakan perwujudan kedaulatan negara tersebut.

Frase "dikuasai oleh Negara dan dipergunakan untuk sebesar-besarnya kemakmuran rakyat", dalam Pasal 33 UUD 1945 jelas menyatakan negara menguasai dan mempergunakan untuk kemakmuran rakyat. Dalam hal ini, menguasai ini dapat dimaknai seperti memberikan izin kepada badan usaha milik negara ataupun swasta nasional atau jika anak negeri belum mampu mengelola dapat memberikan izin kepada badan usaha asing, namun tetap dengan tujuan untuk kemakmuran rakyat Indonesia.

Mempergunakan dapat dimaknai seperti mengelola sebaik-baiknya untuk sebesar-besarnya kemakmuran rakyat, dengan mengutamakan semaksimal mungkin kemampuan sumber daya manusia dan industri dalam negeri dengan prinsip berkeadilan, berkelanjutan, dan berwawasan lingkungan

\section{METODE PENELITIAN}

Penelitian ini bersifat kualitatif dengan jenis data yang digunakan adalah data primer dan sekunder. Pengumpulan data primer dilakukan melalui wawancara dan pengumpulan data sekunder dilakukan melalui studi kepustakaan atau tinjauan literatur.Data sumber penelitian primer diperoleh di lingkungan Kementerian Energi dan Sumber Daya Mineral (ESDM).

Tahapan penilitian melalui kategorisasi (coding) hasil wawancara dan studi kepustakaan berdasarkan frase-frase yang memiliki kesamaan substansi.Lalu, dirangkai dengan narasi, sehingga dapat terlihat bangunan utuh pada tiap kategori untuk dapat ditampilkan pada hasil penelitian.

\section{HASIL DAN PEMBAHASAN}

\section{Hasil}

Implementasi kebijakan pengelolaan energi saat ini masih belum sesuai dengan paradigma pengelolaan energi sebagai modal pembangunan nasional, energi masih dianggap sebagai sumber devisa oleh negara. Padahal untuk mewujudkan kedaulatan energi yang salah satu sumbernya adalah kemandirian, paradimga pengelolaan energi sebagai modal pembangunan bangsa harus dilaksanakan.Sebagai contoh untuk subsektor mineral dan batubara, dalam KEN disebutkan mengurangi ekspor energi fosil secara bertahap terutama gas dan batubara serta menetapkan batas waktu untuk memulai menghentikan ekspor.

Dalam Rencana Umum Energi Nasional (RUEN) dijelaskan dari total produksi batubara nasional sebesar 461,6 juta ton pada tahun 2015 , hanya $20,7 \%$ atau 95,8 juta ton yang dipasok ke pasar domestik, dimana sebagian besar dimanfaatkan oleh pembangkit listrik. Selebihnya, sekitar $79,3 \%$ produksi setara dengan 365,8 juta ton diekspor ke berbagai negara. Hal ini menjadikan Indonesia menjadi negara eksportir batubara terbesar di dunia. Padahal cadangan batubara Indonesia hanya 3,1\% dari cadangan dunia.

Produksi batubara mulai tahun 2019 akan dikendalikan maksimal sebesar 400 juta ton kecuali kebutuhan domestik melebihi 400 juta ton. Ekspor batubara akan dihentikan paling lambat pada tahun 2046 saat kebutuhan domestik mencapai lebih dari 400 juta ton.

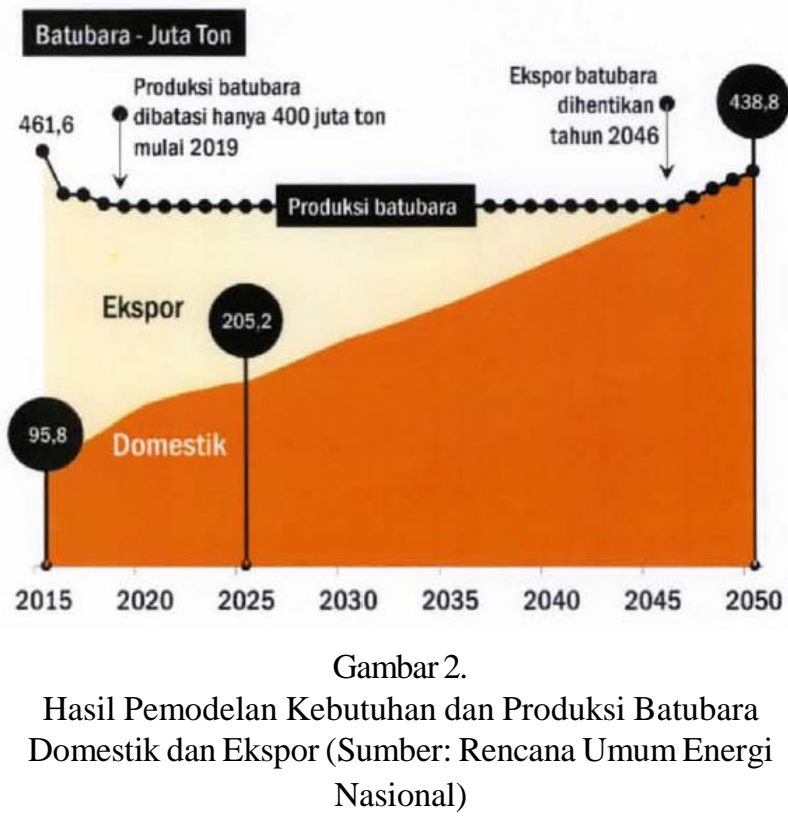

Hasil wawancara salah seorang Kepala Biro di Sekreariat Jenderal Dewan Energi Nasional juga membenarkan hal yang sama mengenai paradigma pengelolaan energi sebagai modal pembangunan nasional yang belum berjalan, khususnya pada subsektor minerba, seperti ekspor batubara yang masih tinggi daripada digunakan untuk dalam negeri. Batubara di dalam negeri dapat digunakan sebagai pasokan utama pembangkit listrik. 
Selain itu, pemanfaatan EBT dalam bauran energi saat ini masih rendah dari target, yang pada tahun 2025 sebesar 23\% dari target bauran energi nasional. Dalam booklet Energi Berkeadilan 4 Tahun Kinerja yang dipublikasikan Kementerian ESDM dijelaskan sampai dengan kuartal ketiga tahun 2018 bauran energi primer pembangkit listrik yang menggunakan EBT sebesar $12,32 \%$.

\section{OPTIMALISASI BAURAN ENERGI PRIMER PEMBANGKIT LISTRIK}
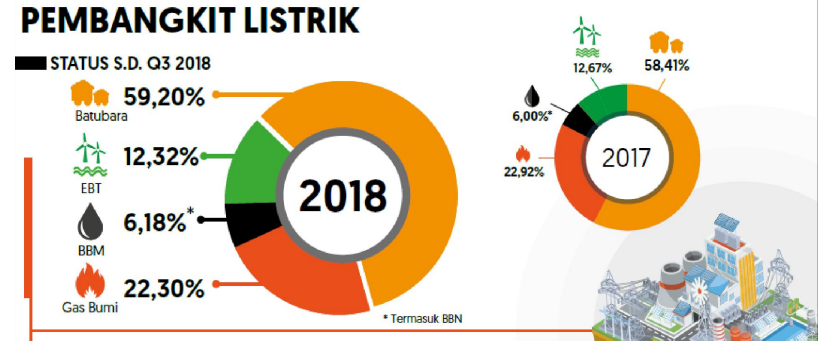

Gambar 3.

Capaian Bauran Energi Primer Pembangkit Listrik. (Sumber: ESDM, Booklet Energi Berkeadilan 4 Tahun Kinerja, 2018, p. 25)

\section{PEMBAHASAN}

Dengan masih belum berjalan secara optimal paradigma energi sebagai modal pembangunan nasional dapat dilihat dari empat aspek, seperti di bawah ini:

\section{Aspek Komunikasi}

Dalam pengelolaan energi yang bertujuan untuk untuk kemakmuran masyarakat diperlukan kejelasan dan konsistensi dalam menerjemahkan kebijakan ke dalam implementasi. Paradigma energi sebagai modal dasar pembangunan sudah ditetapkan dalam KEN dan dijabarkan dalam RUEN, namun apa bila belum maksimal dimungkinkan adanya ketidakjelasan dan ketidakkonsistensian dalam mengimplementasikan kebijakan itu.

Pelaksanaan sosialisasi terhadap kebijakan pengelolaan energi sebagai modal pembangunan nasional sudah kerap kali dilaksanakan, namun sebagai tindakan untuk mengimplementasikannya butuh internalisasi yang jelas dan keajegan pimpinan terhadap bawahan dalam memberikan arahan terhadap kebijakan tersebut.

Sedangkan, masyarakat awam, juga perlu diberikan penjelasan mengenai pentingnya pengelolaan energi sebagai modal pembangunan nasional, seperti contoh pelajar Sekolah umum, santri di Pesantren dan masyarakat kelas menengah ke bawah, agar dapat mengetahui kebijakan energi dan memantau pelaksanaannya, selain para praktisi dan akademisi yang memang berkecimpung di bidang tersebut.

\section{Aspek Sumberdaya}

Untuk mengimplementasikan paradigma pengelolaan energi sebagai modal pembangunan nasional, diperlukan fasilitas dan otoritas yang mumpuni.namun, fasilitas dalam hal ini infrastruktur energi terkendala permasalahan anggaran yang terbatas, seperti pembangunan kilang-kilang baru atau Rencana Induk Pengembangan Kilang (Refinery Development Master Plan/RDMP). Hal tersebut dapat dibuat dengan skema Kerja sama pemerintah dengan Badan Usaha (KPBU) agar meringankan beban Anggaran Pendapatan dan Belanja Negara (APBN).

Pelaksanaan KPBU sudah dilaksanakan dalam infrastruktur energi, seperti pembangunan jaringan gas kota (Jargas) yang dilakukan oleh Badan Usaha seperti Pertamina dan PGN. Namun, kita juga harus menyadari bahwa BU Milik Negara (BUMN) selain di satu sisi harus melaksanakan program pemerintah, di sisi lain harus tetap profit oriented. Diperlukan upaya nyata untuk dapat memberikan dorongan melalui kebijakan yang memberikan keleluasaan BU untuk dapat melaksanakan skema KPBU namun tetap profit oriented, seperti pemberian izin untuk memasarkan di daerah tertentu yang memang infrastrukturnya mereka bangun di tempat tersebut.

Selain itu, Sumber Daya Manusia (SDM) Aparatur perlu diberikan pendidikan dan pelatihan yang mumpuni, agar bias setara dengan aparatur negara-negara maju lainnya. Dengan pemberian penghargaan dan hukuman yang diatur dan dilaksanakan dengan baik, berdasarkan kinerja aparatur tersebut.

\section{Aspek Disposisi}

Kadang kala sebuah kebijakan yang sudah dibuat tidak dapat diimplementasikan bukan karena kebijakan yag dibuat buruk atau formulasinya tidak tepat, melainkan karena paradigma pelaksana atau implementor dalam menjalankan kebijakan paradigma energi sebagai modal pembangunan nasional tidak sepenuh hati. Hal itu bisa disebabkan banyak hal, di antaranya merasa bahwa kebijakan tidak ada manfaatnya sama sekali terhadap implementor dan bahkan memberikan kerja tambahan selain pekerjaan rutinitasnya seharihari.

Sebagai Kementerian yang mengapatkan tugas untuk mengelola keneregian tanah air, Kementerian ESDM terus melakukan reformasi dalam dirinya sendiri, seperti reformasi perizinan yang bertujuan untuk memudahkan investasi. Namun, pada tataran tunjangan terhadap kinerja aparaturnya kementerian ESDM belum mendapatkan tunjangan seperti Kementerian 
yang sudah mendapatkan tunjangan kinerja sebesar seratus persen, saat ini baru sebesar 80 persen, itupun baru tahun 2018 yang disahkan kenaikan melalui Peraturan Presiden Nomor 113 Tahun 2015 tentang Tunjangan Kinerja Pegawai di Lingkungan Kementerian Energi dan Sumber Daya Mineral.

Padahal, bentuk insentif kepada aparatur merupakan hal yang positif dan dapat mendorong kinerja aparatur menjadi lebih baik lagi, mengingat Penerimaan Negara Bukan Pajak (PNBP) tahun 2017, setengah lebih disumbang oleh sektor ESDM, yaitu sebesar Rp. 132 triliun .

\section{Aspek Struktur Birokrasi}

Dalam implementasi paradigma energi sebagai modal pembangunan nasional payung hukum dalam pelaksanaannya diperlukan untuk dapat berjalan secara optimal.Dalam pengembangan EBT, sampai dengan saat ini belum ada Undang-Undang yang mengaturnya padahal untuk menjadi negara yang mandiri energi, diperlukan peraturan yang menjadi landasan dan bahkan daya dorong pengembangannya. Seperti Minerba, Ketenagalistrikan, dan Minyak dan Gas Bumi yang sudah terlebih dahulu memiliki Undang-Undang, maka EBT memerlukan juga Undang-Undang yang mengatur pengelolaannya sehingga dapat tumbuh dan mancapai target yang telah ditetapkan yang didasari fakta (evidence based policy) untuk menghilangkan pembuatan kebijakan yang hanya seumur jagung.

Selain itu, pengelolaan EBT yang saat ini masih bertumpu pada Direktorat Jenderal Energi Baru Terbarukan dan Konservasi Energi (EBTKE) dalam melakukan pelaksanaan pengadaan pembangkit listrik EBT, ke depan dapat didorong seperti pada Direktorat Jenderal Ketenagalistrikan yang dapat dilaksanakan oleh Independent Power Producer (IPP) baik itu BUMN maupun swasta, sehingga resiko dalam tindakan melanggar hukum dapat diminimalisir dan pelaku usaha EBT dapat lebih bergairah dalam mengembangkan EBT.

Jika keempat aspek tadi dijalankan dengan efektif, maka implementasi dari paradigma energi sebagai modal pembangunan nasional bisa dilaksankaan, dengan implementasi tersebut kemandirian dan ketahanan energi yang menjadi sumber kedaulatan energi niscaya terwujud. Untuk itu, perlu agenda dalam pengimplementasian hal tersebut, yaitu:

1) Sampai tahun 2025 target bauran energi untuk EBT dimaksimalkan tercapai yaitu 23 persen, dengan pembuatan Undang-Undang EBT yang mengatur tentang kemudahan investasi EBT agar pengembangan menjadi lebih efisien, tidak seperti saat ini yang cenderung lebih mahal daripada pembangkit listrik berbahan bakar fosil, dorongan bagi pelaku usaha EBT dengan pemberian feed in tarif pada harga jual EBT yang berdasarkan prinsip keekonomian.

2) Sampai tahun 2045 target bauran energi untuk EBT dimaksimalkan tecapai 30 persen, dengan pengembangan EBT yang menjadi prioritas utama. Selain itu, pembatasan ekspor terhadap batubara dan gas bumi yang juga digunakan untuk kepentingan energi tanah air, yang dapat memberikan efek berganda yang akan memberikan nilai tambah pada industri dan terserapnya lapangan kerja anak-anak bangsa.

\section{PENUTUP}

\section{Kesimpulan}

Penelitian ini mendapatkan kesimpulan bahwa (1) pengelolaan energi yang ada saat ini belum mengimplementasikan dengan optimal paradigma energi sebagai modal pembangungan nasional, dan (2) pengelolaan energi yang dibutuhkan untuk keberhasilan visi Indonesia 2045 adalah kelembagaan yang dapat mengimplementasikan paradigma energi sebagai modal pembangunan nasional dengan cara dapat menerjemahkan kebijakan ke dalam implementasi dengan jelas dan konsisten.

Selain itu, perlu dibuat kebijakan yang dapat memberikan skema yang meringankan beban APBN seperti melakukan skema KPBU dalam pengambangan infrastruktur energi, memberikan pendidikan dan pelatihan yang mumpuni kepada aparatur, memberikan tunjangan kepada aparatur dengan layak sesuai dengan pencapaian kinerja dan mendorong pembuatan UU EBT, karena masa depan energi adalah EBT. Jika dapat kesemua hal itu bisa dilaksanakan, bukan tidak mungkin kedaulatan energi akan terwujud.

\section{Saran}

Saran dalam penilitian ini adalah untukmewujudukan kedaulatan energi sudah seharusnya semua pihak dapat mengimplementasikan paradigma energi sebagai pembangunan nasional dengan cara menjadikan energi nilai tambah, sehingga dapat membuka kesempatan kerja dan devisa lebih baik Indonesia.

Penelitian selanjutnya dapat mengembangkan paradigma energi bagi modal pembangunan nasional khususnya sub sektor EBT, yang akan menjadi sumber energi masa depan bangsa Indonesia. 


\section{Daftar Pustaka}

Bappenas. (2018). Indonesia 2045, Berdaulat, Maju, Adill dan Makmur. Jakarta: Bappenas.

Bayraktar, A. (2018, 8 13). From Energy Security to Energy Governance: Turkey's Role in a Globalizing Energy Landscape. Insight Turkey Vol. 17 / No. 2, 45-55.

Dewan Energi Nasional. (2017). Buku Dewan Energi Nasional. Jakarta, Indonesia: Dewan Energi Nasional.

Dye, T. R. (2011). Understanding Pubic Policy. Singapore: Longman.

Edwards III, G. C. (1980). Implementing Public Policy. Washington: Congressional Quarterly Press.

ESDM, K. (2018). Booklet Energi Berkeadilan 4 Tahun Kinerja. Jakarta, Indonesia: Kementerian ESDM.

Khalid, I., \& Mukhtar, A. (2016). Energy Crisis: An Issue of Good Governance, A Way Forward. Journal of Political Studies, Vol. 23, Issue 1, 101.

Khawaja, A. S., \& Ur Rehman, M. S. (2016). Energy Security For pakistan: An Analysis. Journal of Political Studies, Vol. 23, Issue 2, 503-523.

Kurniawati, L. (2017). Kebijakan Dana Ketahanan Energi sebagai Upaya Mewujdukan Ketahanan Energi Nasional: Konsep dan Tentangannya. Jurnal Manajemen Keuangan Publik Vol. 1, No. 1, 29-41.

Nugroho, R. (2015). Policy Making. Jakarta: Elex Media Komputindo Kelompok Gramedia.

Purwanto, E. A., \& Sulistyastuti, D. R. (2015). Implementasi Kebijakan Publik: Konsep dan Aplikasinya di Indonesia. Yogyakarta: CAPS (Center of Academic Publishing Service.

Santoso, R. (2017). KEBIJAKAN ENERGI DI INDONESIA : MENUJU KEMANDIRIAN. Jurnal Analis Kebijakan Volume 1 Nomor 1, 28-36.

Winarno, B. (2014). Kebijakan Publik Teori, Proses dan Studi Kasus. Yogyakarta: CAPS (Center of Academic Publishing Service). 
